\title{
Effects of dry period length and dietary energy source on metabolic status and hepatic gene expression of dairy cows in early lactation
}

\author{
J. Chen, ${ }^{*}$ J. J. Gross, † H. A. van Dorland,† G. J. Remmelink,‡ R. M. Bruckmaier,† B. Kemp, ${ }^{*}$ \\ and A. T. M. van Knegsel*1 \\ *Adaptation Physiology Group, Department of Animal Science, Wageningen University, PO Box 338, 6700 AH Wageningen, the Netherlands \\ †Veterinary Physiology, Vetsuisse Faculty, University of Bern, Bremgartenstrasse 109a, CH-3001 Bern, Switzerland \\ fLivestock Research, Wageningen University and Research Centre, PO Box 65, 8200 AB Lelystad, the Netherlands
}

\section{ABSTRACT}

In a prior study, we observed that cows with a 0 -d dry period had greater energy balance and lower milk production compared with cows with a 30- or 60-d dry period in early lactation. The objective of the current study was to evaluate the influence of dry period length on metabolic status and hepatic gene expression in cows fed a lipogenic or glucogenic diet in early lactation. Holstein-Friesian dairy cows $(\mathrm{n}=167)$ were assigned randomly to $3 \times 2$ factorial design with 3 dry period lengths $(\mathrm{n}=56,55$, and 56 for $0-, 30-$, and 60-d dry, respectively) and 2 early lactation diets $(\mathrm{n}=84$ and 83 for glucogenic and lipogenic diet, respectively). Cows were fed a glucogenic or lipogenic diet from $10 \mathrm{~d}$ before the expected calving date and onward. The main ingredient for a glucogenic concentrate was corn, and the main ingredients for a lipogenic concentrate were sugar beet pulp, palm kernel, and rumen-protected palm oil. Blood was sampled weekly from 95 cows from wk 3 precalving to wk 8 postcalving. Liver samples were collected from 76 cows in wk $-2,2$, and 4 relative to calving. Liver samples were analyzed for triacylglycerol concentrations and mRNA expression of 12 candidate genes. Precalving, cows with a $0-d$ dry period had greater plasma $\beta$-hydroxybutyrate, urea, and insulin concentrations compared with cows with a $30-$ or $60-\mathrm{d}$ dry period. Postcalving, cows with a 0 -d dry period had lower liver triacylglycerol and plasma nonesterified fatty acids concentrations $(0.20,0.32$, and $0.36 \mathrm{mmol} / \mathrm{L}$ for $0-, 30-$, and 60-d dry period, respectively), greater plasma glucose, insulin-like growth factor-I, and insulin (24.38, 14.02 , and $11.08 \mu \mathrm{IU} / \mathrm{mL}$ for $0-, 30-$, and $60-\mathrm{d}$ dry period, respectively) concentrations, and lower hepatic mRNA expression of pyruvate carboxylase, compared with cows with a 30- or 60-d dry period. Plasma urea and $\beta$-hydroxybutyrate concentrations were

Received July 14, 2014.

Accepted October 31, 2014.

${ }^{1}$ Corresponding author: Ariette.vanKnegsel@wur.nl greater in cows fed a lipogenic diet compared with cows fed a glucogenic diet. In conclusion, cows with a $0-d$ dry period had an improved metabolic status in early lactation, indicated by lower plasma concentrations of nonesterified fatty acids, greater plasma concentrations of glucose, insulin-like growth factor-I, and insulin, and lower mRNA expression of pyruvate carboxylase in the liver, compared with cows with a 30- or 60-d dry period. Independent of dry period length, the glucogenic diet also improved the metabolic status compared with the lipogenic diet.

Key words: continuous milking, lipogenic diet, glucogenic diet, liver, energy metabolism

\section{INTRODUCTION}

A traditional 6- to 8-wk dry period has been widely recommended and applied for years to ensure maximum milk production during subsequent lactation. However, these recommendations were primarily based on studies using retrospective analysis of milk yield data from farm records before 1990 (Rastani et al., 2005). Milk production of today's cow has increased considerably (Bachman and Schairer, 2003), and cow health and fertility should also be considered when evaluating the optimal dry period length (Gümen et al., 2005). In recent years, significant discussions have occurred on shortening or omitting the dry period of high-producing dairy cows (Grummer and Rastani, 2004). On the one hand, no or a shortened dry period was shown to result in less milk production in subsequent lactation (Rastani et al., 2005; Schlamberger et al., 2010). On the other hand, several studies demonstrated health benefits of no or a shortened dry period for dairy cows in early lactation. Omitting the dry period increased the plasma concentrations of glucose and insulin and decreased the concentrations of plasma NEFA and BHBA (Andersen et al., 2005), suggesting an improved metabolic status for cows with no dry period, compared with cows with a traditional dry period of $8 \mathrm{wk}$. In addition, shortening the dry period decreased the concentrations of 
plasma NEFA and BHBA in dairy cows in early lactation (Klusmeyer et al., 2009). Moreover, van Knegsel et al. (2014) reported that cows with a 30-d dry period, and in particular, cows with a 0-d dry period had a substantially improved negative energy balance in early lactation compared with cows with a 60-d dry period. Furthermore, a meta-analysis showed that a shortened dry period tends to reduce the risk of ketosis in subsequent lactation (van Knegsel et al., 2013).

As reviewed extensively, dietary strategies can improve the metabolic status of dairy cows during early lactation (Butler, 2003; Chagas et al., 2007). van Knegsel et al. (2007a) showed that a diet high in glucogenic nutrients improved the energy status, indicated by improved energy balance and decreased plasma BHBA and liver triacylglycerol (TAG) concentrations, compared with a diet high in lipogenic nutrients. van Knegsel et al. (2007a), however, tested these diets after a conventional dry period length (60-d). Shortening or omitting the dry period might reduce the requirement for glucogenic nutrients in early lactation because of the improved energy balance and metabolic status. Therefore, it can be hypothesized that the beneficial effects of a glucogenic diet on metabolic status in early lactation are reduced after a shortened or omitted dry period compared with a conventional dry period.

The liver plays an important role in metabolic adaptation in early lactation. Previous studies showed that hepatic adaptation to new lactation is related to altered expression of genes involved in carbohydrate and fatty acid metabolism (Drackley et al., 2001). Pyruvate carboxylase $(\boldsymbol{P C})$ is involved in carbohydrate metabolism, which was earlier reported to have an altered expression during the transition from pre- to postcalving (Greenfield et al., 2000). The altered expression during the transition from pre- to postcalving was also observed for genes carnitine palmitoyltransferase $1 \mathrm{~A}(\boldsymbol{C P T 1} \boldsymbol{A})$ and carnitine palmitoyltransferase 2 (CPT2), which were involved in fatty acid oxidation (Graber et al., 2010). Loor et al. (2005) reported that the expression of gene glycerol-3-phosphate acyltransferase mitochondrial ( $\boldsymbol{G P A} \boldsymbol{M})$ involved in liver TAG synthesis decreased from pre- to postcalving. In addition, it can be hypothesized that also the expression of 3-hydroxybutyrate dehydrogenase 2 (BDH2) and 3-hydroxy-3-methylglutaryl-coenzyme A synthase 2 (HMGCS2) change during the transition from pre- to postcalving, because BDH2 and HMGCS2 are considered to be involved in the process of ketone body synthesis (Graber et al., 2010). The gene expression of acute phase proteins, serum amyloid-A $(\boldsymbol{S A} \boldsymbol{A})$ and haptoglobin $(\boldsymbol{H p})$, and $I G F-I$ also changed during the transition from pre- to postcalving (Radcliff et al., 2003; Gessner et al., 2013). Moreover, although the ruminant liver is not a lipogenic tissue (Khan et al., 2014), Ballard et al. (1972) reported that lipogenic enzyme such as ATP citrate lyase (ACLY) could respond to a high carbohydrate diet; hence, the expression of $A C L Y$ and acetyl-CoA-carboxylase $(\boldsymbol{A} \boldsymbol{C} \boldsymbol{C})$ may be expected to be affected by a dietary energy source. To our knowledge, information on the effect of dry period length on expression of genes involved in carbohydrate or fatty acid metabolism, and inflammatory processes in dairy cows is scarce. Therefore, the objective of this study was to evaluate the influence of dry period length on metabolic status and hepatic gene expression in cows fed a lipogenic or glucogenic diet during early lactation.

\section{MATERIALS AND METHODS}

\section{Animals and Experimental Design}

The Institutional Animal Care and Use Committee of Wageningen University approved the experimental protocol. Holstein-Friesian dairy cows $(\mathrm{n}=167)$ were selected from the Dairy Campus Research dairy herd (WUR Livestock Research, Lelystad, the Netherlands). The experimental design, dry period lengths, and dietary contrasts were described by van Knegsel et al. (2014). In summary, cows were blocked for parity (primiparous or multiparous), expected calving date, milk yield in the previous lactation, and BCS. Within blocks, each cow was assigned randomly to a $3 \times 2$ factorial design with 3 dry period lengths (0-, 30-, or 60-d) and 2 early lactation diets (glucogenic or lipogenic).

During the precalving period, lactating cows were fed a lactation diet supporting $25 \mathrm{~kg}$ of milk, and dry cows were fed a dry cow ration. From d 10 before the expected calving date and onward, cows of all treatments were fed $1 \mathrm{~kg} / \mathrm{d}$ of glucogenic or lipogenic concentrate and increased postcalving stepwise with 0.5 $\mathrm{kg} / \mathrm{d}$ until the concentrate supply reached $8.5 \mathrm{~kg} / \mathrm{d}$. The main ingredient for the glucogenic concentrate was corn, and the main ingredients for the lipogenic concentrate were sugar beet pulp, palm kernel, and rumen protected palm oil. Forage was supplied ad libitum and was composed of grass silage, corn silage, wheat straw, and rapeseed meal or soybean meal (51:34:2:13, DM basis). Diets were formulated to be isocaloric (net energy basis; VEM system; Van Es, 1975) and equal in intestinal digestible protein and degraded protein balance (DVE/OEB system; Tamminga et al., 1994).

Blood samples were collected from $95(\mathrm{n}=64 \mathrm{mul}-$ tiparous and $n=31$ primiparous) of the 167 cows, and liver biopsies were collected from $76(\mathrm{n}=51$ multiparous and $n=25$ primiparous) of the 167 cows for liver TAG analysis and from $67(\mathrm{n}=48$ multiparous and $\mathrm{n}$ $=19$ primiparous) of the 167 cows for gene expression 
Table 1. Distribution of cows per dry period length $(0-, 30-$, or $60-\mathrm{d})$ and $\operatorname{diet}^{1}$

\begin{tabular}{|c|c|c|c|c|c|c|c|}
\hline \multirow[b]{2}{*}{ Cows, no. } & \multicolumn{2}{|c|}{0} & \multicolumn{2}{|c|}{30} & \multicolumn{2}{|c|}{60} & \multirow[b]{2}{*}{ Total } \\
\hline & G & $\mathrm{L}$ & $\mathrm{G}$ & $\mathrm{L}$ & G & $\mathrm{L}$ & \\
\hline Cows in experiment & 28 & 28 & 28 & 27 & 28 & 28 & 167 \\
\hline Blood sampling & 16 & 15 & 17 & 17 & 15 & 15 & 95 \\
\hline Liver biopsy for $\mathrm{TAG}^{2}$ analysis & 14 & 12 & 14 & 12 & 12 & 12 & 76 \\
\hline Liver biopsy for gene expression analysis & 12 & 12 & 11 & 11 & 11 & 10 & 67 \\
\hline
\end{tabular}

analysis. Table 1 shows the distribution of cows per dry period length and diet. Cows were housed in a free stall with a slatted floor and cubicles and were milked twice daily (0500 and $1630 \mathrm{~h}$ ).

\section{Blood Sampling and Analysis}

Blood samples were taken weekly from the coccygeal vein from wh -3 to 8 relative to calving date at $3 \mathrm{~h}$ before the morning feeding. Blood was collected in evacuated tubes (Vacuette, Greiner BioOne, Kremsmunster, Austria) containing NaF for glucose; EDTA for insulin, NEFA, BHBA, and urea analysis; or heparin for IGF-I. Samples were kept cold on ice for a maximum of $2 \mathrm{~h}$ until they were centrifuged at $2,900 \times g$ for $10 \mathrm{~min}$ at $4^{\circ} \mathrm{C}$. Plasma was decanted, aliquoted, and frozen at $-20^{\circ} \mathrm{C}$ until analysis. Plasma samples were analyzed at a laboratory of the Veterinary Physiology group (Veterinary Physiology, Vetsuisse Faculty, University of Bern, Bern, Switzerland). Concentrations of glucose and urea were measured using commercial kits no. 61269 and no. 61974 from BioMérieux (Marcy l'Etoile, France), as previously described (Graber et al., 2012). Concentrations of NEFA and BHBA were measured enzymatically using kit no. 994-75409 from Wako Chemicals (Neuss, Germany) and kit no. RB1007 from Randox Laboratories (Ibach, Switzerland), as previously described (Graber et al., 2012). Insulin-like growth factor-1 and insulin were measured using RIA, as previously described (Vicari et al., 2008).

\section{Liver Tissue Sampling and Triacylglycerol Analysis, mRNA Extraction, and Quantitative Real-Time Reverse Transcription-PCR}

Liver biopsies were taken in wk $-2,2$, and 4 relative to calving. Before taking the biopsy, the biopsy site was clipped and disinfected. Liver biopsies (approximately $400 \mathrm{mg}$ of wet weight) were obtained through an incision at the location of the greater trochanter at the 11th intercostal space on the right side of the cow. A biopsy was obtained under local anesthesia $(7 \mathrm{~mL}$, of lidocaine- $\mathrm{HCl} 2 \%$ with adrenaline, Alfasan Nederland, B.V., Woerden, the Netherlands) and was harvested by moving the biopsy needle $(17$ gauge $\times 200 \mathrm{~mm})$ several times. Tissue samples for TAG determination were kept cold on ice in a $0.9 \% \mathrm{NaCl}$ solution for a maximum for $2 \mathrm{~h}$ and subsequently stored at $-20^{\circ} \mathrm{C}$ until analysis. Tissue samples for the gene expression analysis were collected in a RNA stabilization reagent (RNAlater from Ambion, Applied Biosystems Business, Austin, TX), kept at $4^{\circ} \mathrm{C}$ for $24 \mathrm{~h}$, and subsequently stored at $-80^{\circ} \mathrm{C}$ until analysis.

Liver TAG was extracted from liver samples (approximately $150 \mathrm{mg}$ of wet weight) using $0.5 \mathrm{~mol} / \mathrm{L}$ of $\mathrm{KOH}$ in ethanol for $30 \mathrm{~min}$ at $70^{\circ} \mathrm{C}$, and then 2.5 $\mathrm{mol} / \mathrm{L}$ of perchloric acid was added to neutralize the mixture. Concentration of liver TAG was determined though enzymatic colorimetric analysis using the Triacylglycerols LiquiColor Mono kit (Human Gesellschaft fur Biochemica undDiagnostica mbH, Wiesbaden, Germany) according to the manufacturer's instructions.

Gene expression in liver tissue was analyzed according to Graber et al. (2012). In short, total RNA was extracted from liver samples (approximately 100 mg of wet weight) with pepGOLD TriFast (PEQLAB Biotechnologie GmbH, Erlangen, Germany) according to the manufacturer's protocol. Quality of the RNA was determined by measuring absorbance at 260 and $280 \mathrm{~nm}$, followed by gel electrophoresis with ethidium bromide staining. One microgram of total RNA was reverse transcribed with 200 U of Moloney Murine Leukemia Virus Reverse Transcriptase RNase H minus, Point Mutant (Promega Corp., Madison, WI) using random hexamer primers (Invitrogen, Leek, the Netherlands). The obtained cDNA was diluted to a final concentration of $10 \mathrm{ng} / \mu \mathrm{L}$ and stored at $-20^{\circ} \mathrm{C}$.

Relative gene expression were assessed though realtime quantitative reverse-transcription PCR using a Rotor-Gene 6000 rotary analyzer (Corbett Research, Sydney, Australia) using the software version 1.7.75. Primers sequences and annealing temperatures for candidate genes were used as previously described: ACC, BDH2, CPT1A, CPT2, GPAM, HMGCS2, and 
$P C$ (Graber et al., 2010), ACLY (van Dorland et al., 2009), IGF-I (Gross et al., 2011), SAA, Hp, and tumor necrosis factor- $\alpha(\boldsymbol{T N F}-\boldsymbol{\alpha}$; Zarrin et al., 2014). For each assay, a master mix was prepared that consisted of $0.8 \mu \mathrm{L}$ of water, $1.0 \mu \mathrm{L}$ of forward primer $(5$ pmol), $1.0 \mu \mathrm{L}$ of reverse primer $(5 \mathrm{pmol}), 0.2 \mu \mathrm{L}$ of 50 $\times$ SYBR-Green $(20 \mathrm{pmol})$, and $5.0 \mu \mathrm{L}$ of $2 \times$ SensiMix (1 $\mathrm{mM} \mathrm{MgCl} 2 ; 2 \times$ SensiMix NoRef DNA Kit). The reverse-transcription PCR was performed using $2 \mu \mathrm{L}$ of sample volume (containing $20 \mathrm{ng}$ of cDNA) with 8 $\mu \mathrm{L}$ of master mix. The PCR temperature profile consisted of $10 \mathrm{~min}$ incubation at $95^{\circ} \mathrm{C}$. Cycling conditions consisted of 40 cycles of $15 \mathrm{~s}$ at $95^{\circ} \mathrm{C}$, optimal annealing temperature for each individual gene for $30 \mathrm{~s}$, and extension at $72^{\circ} \mathrm{C}$ for $20 \mathrm{~s}$, followed by a melting curve program $\left(60-95^{\circ} \mathrm{C}\right)$. All samples were assayed on the same run to eliminate interassay variation. The mRNA expression of the target genes were calculated relative to the average mRNA expression of 2 housekeeping genes, GAPDH and ubiquitin. Stabilities of GAPDH and ubiquitin were assessed across all samples using the geNorm program in the current study (M-value = 0.163; Vandesompele et al., 2002). Primer information of the housekeeping genes are shown in Zarrin et al. (2014). The sizes of the obtained PCR products were verified by gel electrophoresis.

\section{Statistical Analysis}

Repeated measures ANOVA (PROC MIXED, SAS version 9.1, SAS Institute Inc., Cary, NC) were performed for data analysis. The cow was considered as the repeated subject. Because preliminary analysis showed that the interaction effect of diet $\times$ week was not significant $(P>0.05)$, it was excluded from the model.

Statistical analyses were performed separately for precalving and postcalving data of plasma metabolites and hormones. Precalving, dry period length (0-, 30-, or $60-\mathrm{d})$, diet (glucogenic or lipogenic), parity $(2,3$, or $>3$ ), week (wk -3 to -1 for plasma metabolites and hormones; not included in the liver TAG model), and their interactions were included as fixed effects. Postcalving, dry period length (0-, 30-, or 60-d), diet (glucogenic or lipogenic), parity $(2,3$, or $>3$ ), week (wk 1 to 8 for plasma metabolites and hormones; wk 2 and 4 for liver TAG), and their interactions were included as fixed effects. Plasma BHBA concentrations postcalving were $\log _{2}$ transformed before analysis to obtain normal distribution of residuals.

The mRNA expression of the target genes normalized by housekeeping genes was $\log _{2}$ transformed before analysis. Gene expression (delta cycle threshold, $\log _{2}$ ) was analyzed using dry period length (0-, 30-, or 60-d), diet (glucogenic or lipogenic), parity $(2,3$, or $>3$ ), and their interaction as fixed effects. To study the effect of time on mRNA expression, dry period length (0-, 30-, or $60-\mathrm{d}$ ), diet (glucogenic or lipogenic), parity $(2,3$, or $>3$ ), and week (wk $-2,2$, and 4 ) were included as fixed effects.

For plasma metabolites, hormones, and mRNA expression, a first-order autoregressive structure $[\mathrm{AR}(1)]$ was the best fit and was used to account for within-cow variations. For liver TAG concentrations, the compound symmetry structure was the best fit and was used to account for within-cow variations. Model assumptions were evaluated by examining the distribution of residuals. For comparison of dry period lengths, $P$-values are presented after a Bonferroni adjustment. Values are presented as least squares means with their standard errors of the mean. Differences are regarded as significant if $P<0.05$, and trends are discussed if $P \leq 0.10$.

\section{RESULTS}

\section{Dry Period Length, Energy Balance, DMI, and Animal Performance}

Actual days dry were $4 \pm 1,30 \pm 1$, and $61 \pm 1$ $\mathrm{d}$ (means \pm SEM) for cows with a $0-, 30-$, or $60-\mathrm{d}$ dry period length treatments, respectively. Results of energy balance, DMI, milk yield, and BW were previously reported (van Knegsel et al., 2014). In short, milk production in the last $8 \mathrm{wk}$ before calving was 13.8 \pm 0.5 and $7.7 \pm 0.5 \mathrm{~kg} / \mathrm{d}$ for cows with a 0 - or $30-\mathrm{d}$ dry period, respectively. Precalving, DMI was greater for cows with a 0- or 30-d dry period compared with cows with a 60-d dry period, but energy balance was greater for cows with a 60-d dry period. Postcalving, milk yield was lower ( 32.7 vs. 38.7 vs. $43.3 \pm 0.7 \mathrm{~kg} / \mathrm{d}$ for the 0 - vs. 30 - vs. 60 -d dry period, respectively, $P$ $<0.01$ ), whereas energy balance (39 vs. -59 vs. -132 $\pm 14 \mathrm{~kJ} / \mathrm{kg}^{0.75 *} \mathrm{~d}$ for the 0 - vs. 30 - vs. 60 -d dry period, respectively, $P<0.01$ ), BW (691 vs. 660 vs. $665 \pm 7$ $\mathrm{kg}$ for 0 - vs. 30- vs. 60-d dry period, respectively, $P$ $<0.01)$, and BCS (3.0 vs. 2.5 vs. $2.2 \pm 0.1 \mathrm{~kg}$ for the 0 - vs. 30 - vs. 60 -d dry period, respectively, $P<0.01$ ) were greater for cows with a 0-d dry period compared with cows with a $30-$ or $60-d$ dry periods. Postcalving, dry period length did not affect DMI.

\section{Plasma Metabolites, Hormones, and Liver TAG}

Precalving, the concentrations of plasma metabolites and hormones are shown in Table 2. Precalving, plasma NEFA concentrations (Figure $1 \mathrm{~A})$ were lower $(P<$ 0.01 ) for cows with a 0-d dry period compared with cows with a 60-d dry period. Plasma BHBA (Figure 
$1 \mathrm{~B}$ ), urea (Figure $1 \mathrm{C}$ ), and insulin (Figure $1 \mathrm{D}$ ) concentrations were greater $(P<0.01)$ for cows with a 0 -d dry period compared with cows with a 30- or 60-d dry period. Plasma glucose concentrations (Figure 1 E) did not differ among dry period lengths, but a dry period length $\times$ week interaction $(P=0.03)$ showed that plasma glucose concentrations increased from wk -3 until calving for cows with a 0 -d dry period but decreased during the same period for cows with a 30- or 60-d dry period. Dry period length $\times$ week interaction for plasma IGF-I concentration (Figure $1 \mathrm{~F}$ ) was found showing a lower decrease in IGF-I concentrations for cows with a 0-d dry period compared with cows with a 30- or 60-d dry period in early lactation $(P<$ 0.01). Liver TAG concentrations (Figure 2) were lower for cows with a 0-d dry period, compared with cows with a 30 - or $60-\mathrm{d}$ dry period $(P=0.03)$. Young cows $($ parity $=2)$ with a 0 -d dry period had lower liver TAG concentrations (9.91 vs. 16.01 vs. $21.71 \pm 2.77 \mathrm{mg} / \mathrm{g}$ for the 0- vs. 30- vs. $60-\mathrm{d}$ dry period, respectively; $P=$ 0.04). In older cows, no effects of dry period length on liver TAG concentrations were found (10.45 vs. 13.67 vs. $11.86 \pm 1.15 \mathrm{mg} / \mathrm{g}$ for 0 - vs. 30 - vs. 60 -d dry period, respectively; $P=0.66$ ).

Postcalving, cows with a 0 -d dry period had lower $(P$ $<0.01)$ plasma NEFA and liver TAG concentrations compared with cows with a 30 - or 60 -d dry period (Table $3)$. The dry period length did not affect plasma BHBA or urea concentrations. Plasma glucose, IGF-I, and insulin concentrations were greater $(P<0.01)$ for cows with a 0 -d dry period compared with cows with a 30- or 60-d dry period. Plasma NEFA, urea, insulin, glucose, IGF-I, and liver TAG $(P<0.01)$ concentrations were different over time. Plasma IGF-I $(P=0.03)$, glucose $(P=0.04)$, and liver TAG $(P=0.03)$ concentrations were affected by dry period length $\times$ week interaction. Additionally, plasma BHBA $(P=0.02)$, glucose $(P=$ $0.02)$, and insulin $(P<0.01)$ concentrations were affected by dry period length $\times$ parity interaction.

For both precalving and postcalving period, diet did not affect plasma NEFA, insulin, glucose, IGF-I, or liver TAG concentrations. Precalving, plasma urea concentrations tended to be lower for cows fed a glucogenic diet compared with cows fed a lipogenic diet $(P=$ 0.07). Postcalving, plasma urea $(P<0.01)$ and BHBA $(P=0.01)$ concentrations were lower for cows fed the glucogenic diet compared with cows fed the lipogenic diet. Postcalving, plasma BHBA concentrations were affected by the ration $\times$ parity interaction $(P<0.01)$. In contrast to the lipogenic diet, the glucogenic diet resulted in a lower plasma BHBA concentration for young cows $(0.50 \pm 0.05 \mathrm{mmol} / \mathrm{L}$ vs. $0.68 \pm 0.05 \mathrm{mmol} / \mathrm{L}, P$ $<0.01)$, but not for older cows $(0.67 \pm 0.04 \mathrm{mmol} / \mathrm{L}$ vs. $0.64 \pm 0.04 \mathrm{mmol} / \mathrm{L}, P=0.52)$.

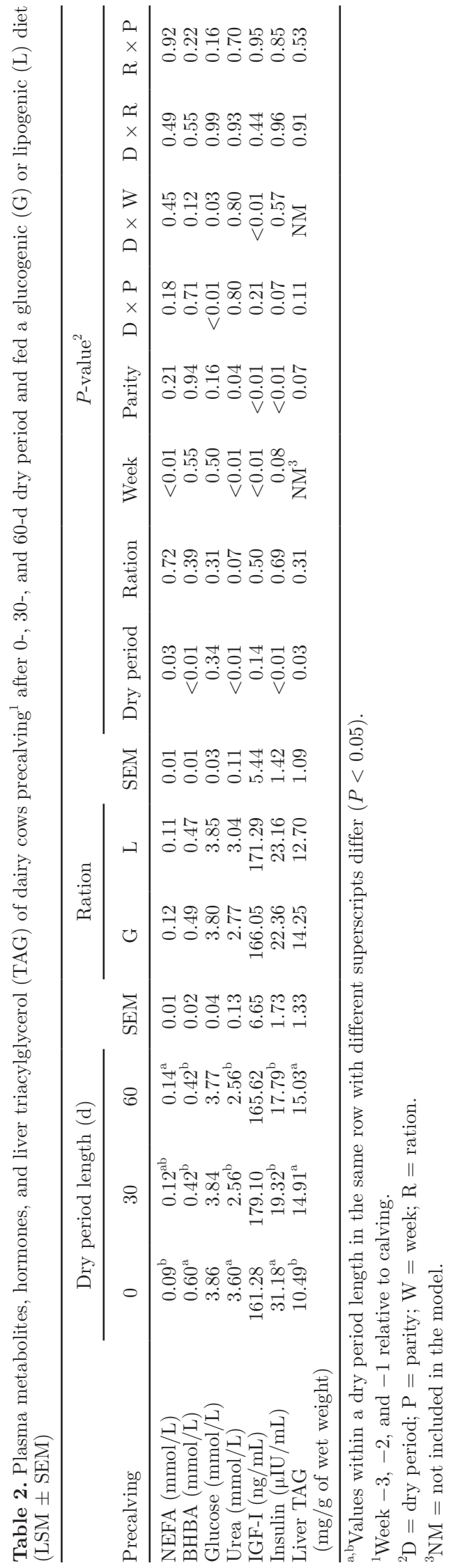

Journal of Dairy Science Vol. 98 No. 2, 2015 
A)
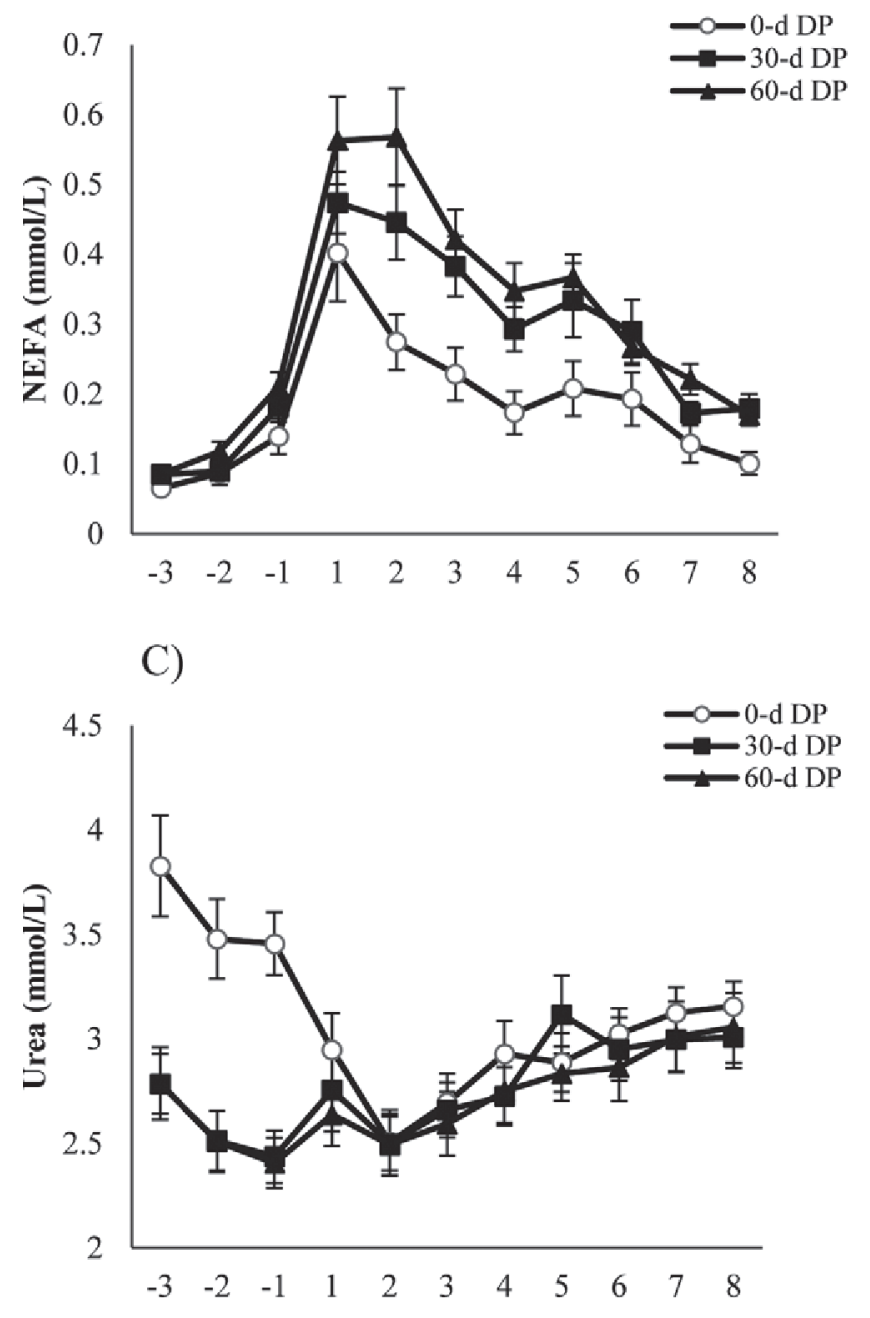

E)

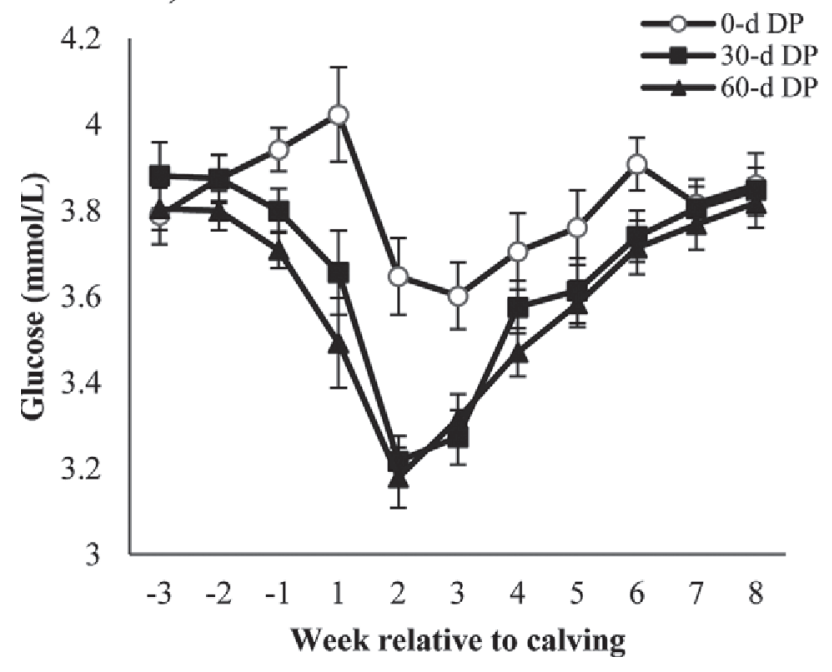

B)

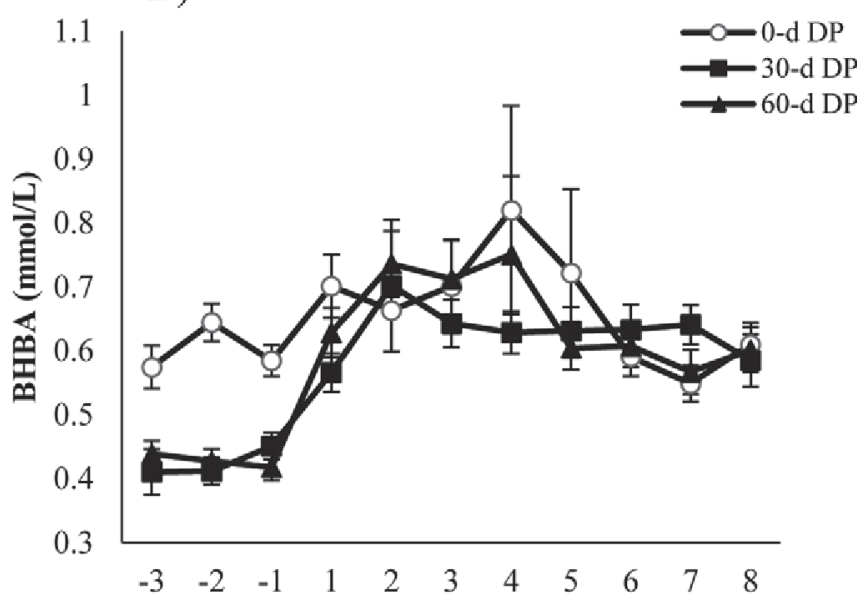

D)

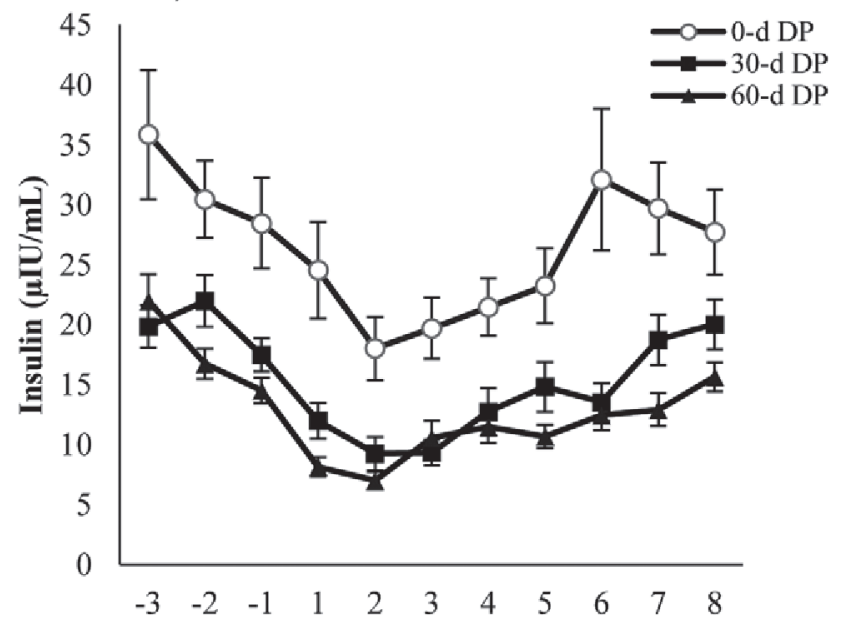

F)

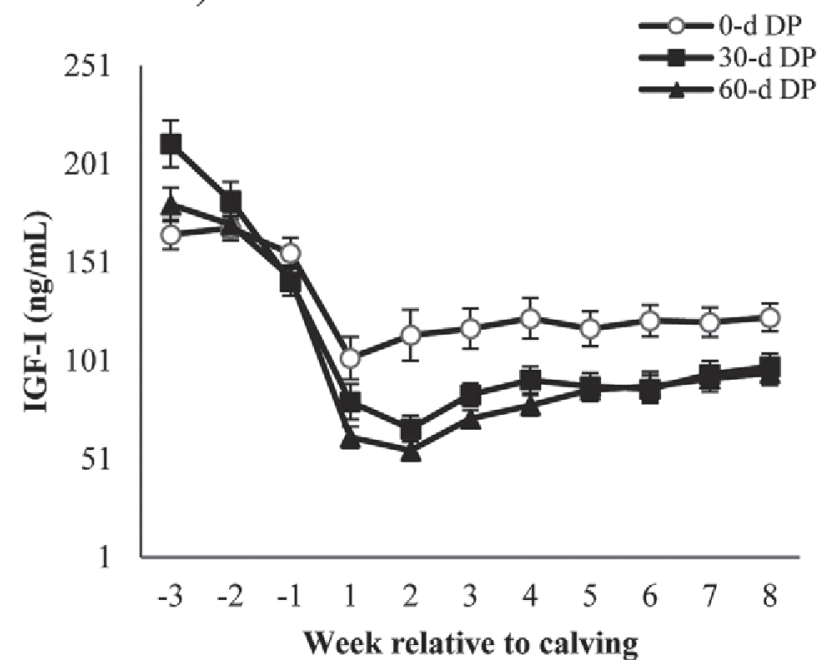

Figure 1. A) Plasma NEFA (mmol/L), B) plasma BHBA (mmol/L), C) plasma urea (mmol/L), D) plasma insulin $(\mu \mathrm{IU} / \mathrm{mL}), \mathrm{E}) \mathrm{plasma}$ glucose $(\mathrm{mmol} / \mathrm{L})$, and F) plasma IGF-I $(\mathrm{ng} / \mathrm{mL})$ for cows with a 0-, 30-, or 60-d dry period (DP) during wk -3 to 8 relative to calving. Values represent means $( \pm \mathrm{SEM})$ per DP length per week. 


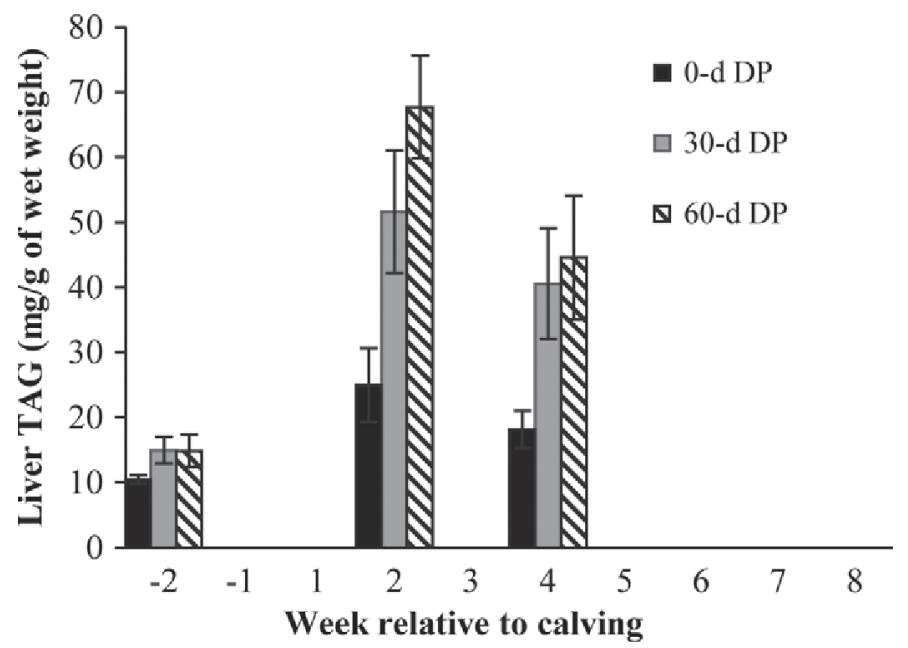

Figure 2. Liver triacylglycerol (TAG; $\mathrm{mg} / \mathrm{g}$ of wet weight) for cows with a $0-, 30-$, or $60-$ d dry period (DP) in wk $-2,2$, and 4 relative to calving. Values represent means $( \pm \mathrm{SEM})$ per DP length per week.

\section{mRNA Expression of Genes in Liver}

The mRNA expression of CPT1A and CPT2 did not differ among dry period lengths (Table 4). The mRNA expression of CPT2 was increased from wk -2 to 2 for all dry period lengths $(P<0.01)$.

The mRNA expression of $P C$ was lower for cows with a 0-d dry period compared with cows with a $30-$ or 60 -d dry period in wk $4(P<0.01)$. No differences in the mRNA expression of $I G F-I$ were found among dry period lengths. The mRNA expression of $P C$ was increased from wk -2 to 2 or 4 for all dry period lengths $(P<0.01)$. In contrast, mRNA expression of $I G F-I$ was decreased from wk -2 to 2 or 4 for all dry period lengths $(P<0.01)$.

The mRNA expression related to fatty acid and triacylglycerol synthesis ( $A C L Y, G P A M$, and $A C C)$ and to ketone body synthesis (BDH2 and HMGCS2) did not differ among the dry period lengths. The mRNA expression of GPAM was decreased from wk -2 to 2 for all dry period lengths $(P<0.01)$, whereas the mRNA expression of $A C C$ was increased from wk -2 to 4 for all dry period lengths $(P=0.03)$. The mRNA expression of $A C L Y$ was decreased from wk 2 to 4 for all dry period lengths $(P=0.03)$.

The mRNA expression of $S A A, H p$, and $T N F-\alpha$ did not differ among the dry period lengths. The mRNA expression of $H p$ increased from wk -2 to 2 for all dry period lengths $(P<0.01)$. The mRNA expression of $S A A$ tended to increase from wk -2 to 2 for all dry period lengths $(P=0.06)$.

Diet had no effects on the mRNA expression of $C P$ T1A, CPT2, PC, IGF-I, ACLY, ACC, GPAM, BDH2, $H M G C S 2, S A A, H p$, and $T N F-\alpha$ for all time points. 
Table 4. Gene expression (delta cycle threshold, $\log _{2}$ ) in liver in dairy cows after 0-, 30-, and 60-d dry period and fed a glucogenic (G) or lipogenic (L) diet (LSM \pm SEM)

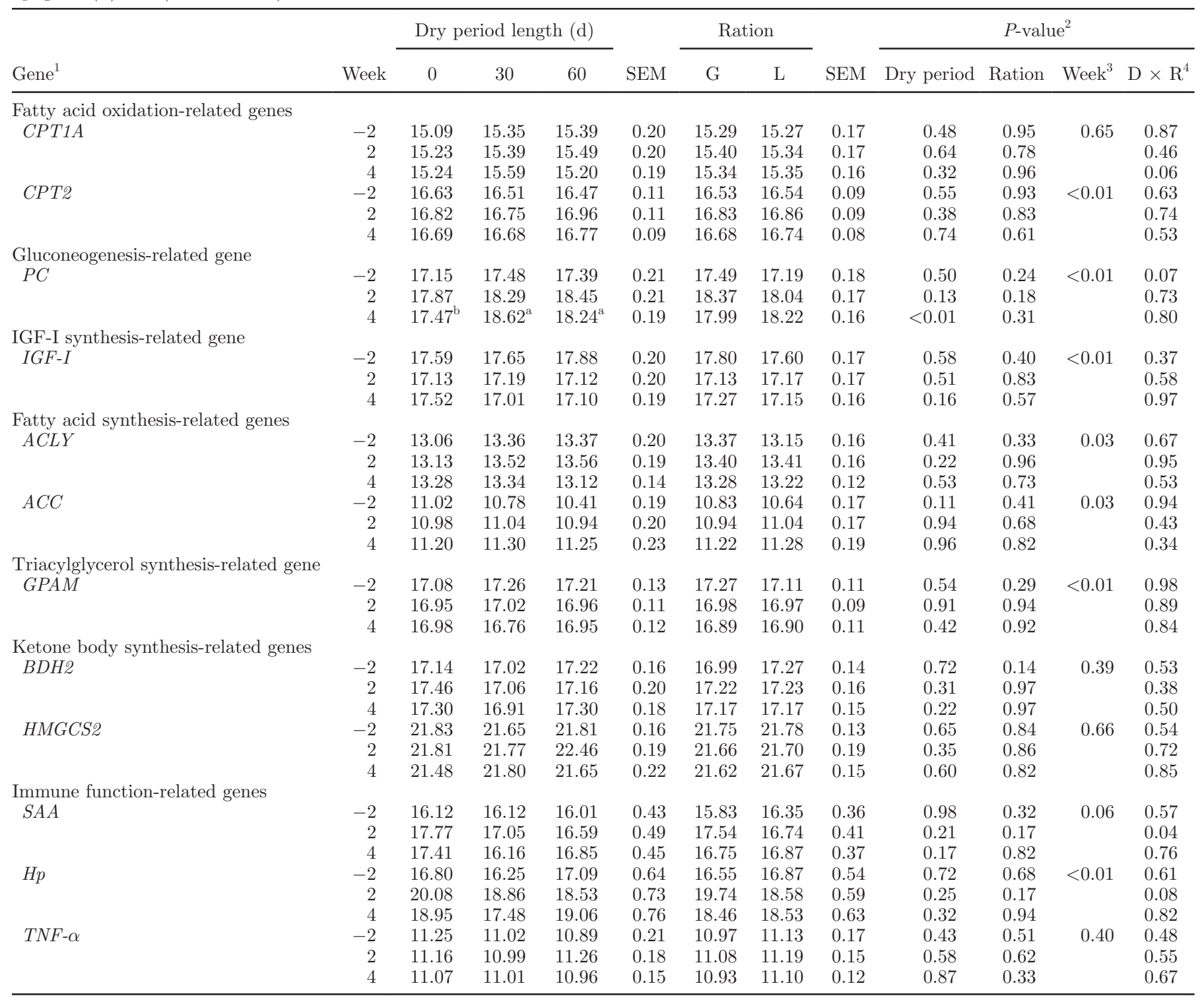

${ }^{\mathrm{a}, \mathrm{b}}$ Values within dry period length in the same row with different superscripts differ $(P<0.05)$.

${ }^{1} A C L Y=$ ATP citrate lyase; $A C C=$ acetyl-CoA-carboxylase; $B D H 2=3$-hydroxybutyrate dehydrogenase $2 ; C P T 1 A=$ carnitine palmitoyltransferase 1A; CPT2 = carnitine palmitoyltransferase 2; GPAM = glycerol-3-phosphate acyltransferase mitochondrial; HMGCS2 = 3-hydroxy3-methylglutaryl-coenzyme A synthase $2 ; H p=$ haptoglobin; $I G F-I=$ insulin-like growth factor-I; $P C=$ pyruvate carboxylase; $S A A=$ serum amyloid-a; $T N F-\alpha=$ tumor necrosis factor- $\alpha$.

${ }^{2}$ The $P$-value of parity and interaction of dry period $\times$ parity and ration $\times$ parity not shown in table.

${ }^{3}$ Week $-2,2$, and 4 relative to calving.

${ }^{4} \mathrm{D}=$ dry period; $\mathrm{R}=$ ration.

\section{DISCUSSION}

In the current study, plasma glucose concentrations were greater in cows with a 0-d dry period compared with cows with a $30-$ or $60-$ d dry period in early lactation after calving. Earlier, we showed that cows with a reduced (0- or 30-d) dry period had a lower milk yield and milk lactose production compared with cows with a 60-d dry period (van Knegsel et al., 2014). Dry period length did not affect DMI in early lactation. Lower milk production and lower lactose production results in a reduced requirement of glucose by the mammary gland (Lemosquet et al., 2009). Herewith, with an equal DMI, omitting the dry period seems to result in repartitioning 
of glucose from milk to body reserves, as indicated by elevated plasma insulin concentrations and improved energy balance (van Knegsel et al., 2014).

In lactating dairy cows, the whole-body glucose flux is primarily derived from hepatic gluconeogenesis. $\mathrm{Ru}-$ minal propionate is the primary substrate for gluconeogenesis in dairy cows (Drackley et al., 2001). The increased demand for glucose precursors in early lactation, however, cannot be met by ruminal propionate completely because of relatively low DMI. Lower DMI leads to reduced glucose synthesis from propionate, whereas more endogenous precursors (lactate, glycerol, and amino acids) are used as gluconeogenic substrate (Greenfield et al., 2000). Aschenbach et al. (2010) indicated that increased hepatic mRNA expression of $P C$ was critical in gluconeogenesis from endogenous precursors during the transition from pre- to postcalving. In the current study, mRNA expression of $P C$ was lower for cows with a 0-d dry period in wk 4 after calving, compared with cows with a 30- or 60-d dry period. The lower mRNA expression of $P C$ in cows with a 0 -d dry period suggests that omitting the dry period results in lower rate of gluconeogenesis from endogenous precursors in the liver compared with cows with a $30-$ or $60-\mathrm{d}$ dry period. These results support our hypothesis that reducing the dry period decreases the demand for glucose in the mammary gland of dairy cows. In addition, $P C$ mRNA expression increased after calving for all dry period lengths and was lower for cows with a 0 -d dry period compared with cows with a $30-$ or $60-d$ dry period at wk 4 . This indicates a shorter recovery time in early lactation from elevated hepatic gluconeogenic activity from endogenous precursors in these cows.

In the current study, omitting the dry period increased plasma insulin concentrations compared with a 30 - or 60-d dry period in early lactation, which is in line with previous studies (Andersen et al., 2005; de Feu et al., 2009). In early lactation, the elevation of plasma insulin plays a key role in coupling the GH-IGF axis. It is well known that the liver is the major contributor of plasma IGF-I (Radcliff et al., 2003). During negative energy balance, however, hepatic IGF-I synthesis is reduced because of GH resistance in the liver, which is related to downregulation of the hepatic GH receptor (GHR; Lucy et al., 2001). In the current study, plasma IGF-I concentrations were greater for cows with a 0-d dry period compared with cows with a 30- or 60-d dry period. Butler et al. (2003) suggested that the greater plasma IGF-I concentration is associated with an insulin-induced increase of $I G F-I$ and $G H R$ mRNA expression in the liver. The mRNA expression of $I G F-I$ in the liver, however, did not differ among dry period lengths in this study, which was unexpected. Grala et al. (2011) also observed no correlation between plasma
IGF-I concentration and hepatic $I G F-I$ mRNA expression in the first week after calving. They attributed this to more variable data or posttranslational modification.

In early lactation, increased mobilization of adipose tissue is associated with hypoinsulinemia or decreased insulin sensitivity or both (Bell, 1995). High insulin concentration was reported to decrease responsiveness to GH in adipose tissue by inhibiting GHR expression and, thus, suppressing lipolysis (Butler et al., 2003). The decreased rate of lipolysis results in decreased plasma NEFA concentration (Locher et al., 2011). Thus, lower plasma NEFA concentrations in cows with a $0-d$ dry period, compared with cows with a $30-$ or 60-d dry period reflects decreased fat mobilization, which is in agreement with the greater energy balance and BCS in these cows, as previously reported (van Knegsel et al., 2014). Schlamberger et al. (2010) also reported that continuous milking (0-d dry period) resulted in lower plasma NEFA concentrations during the first $8 \mathrm{wk}$ of lactation compared with a 56-d dry period.

Nonesterified fatty acids can be esterified and stored as TAG in liver. In the current study, the lower plasma NEFA concentrations may explain the lower liver TAG concentrations in cows with a 0-d dry period, compared with cows with a 30- or 60-d dry period. Bobe et al. (2004) suggested that cows with a moderate (50 to 100 $\mathrm{mg} / \mathrm{g}$ liver TAG on a wet weight basis) or severe fatty liver $(>100 \mathrm{mg} / \mathrm{g}$ of liver TAG) were at high risk for metabolic and reproductive problems. The GPAM gene encodes the mitochondrial isoform of enzyme glycerol3-phosphate-acyltransferase. During liver TAG synthesis, GPAM catalyzes the first step of glycerolipid synthesis: addition of fatty acids to glycerol-3-phosphate to form lysophosphatidic acid (Takeuchi and Reue, 2009). In the current study, no differences in mRNA expression of GPAM were found among dry period lengths, despite the fact that cows with a 0-d dry period had lower liver TAG concentrations. Loor et al. (2006) suggested that the GPAM is not rate limiting for TAG accumulation in the liver.

Although NEFA can be used for ketogenesis through mitochondrial oxidation, dry period length did not affect plasma BHBA concentrations in this study. It was suggested that plasma NEFA concentration does not determine the extent of $\beta$-oxidation and plasma BHBA concentration in periparturient dairy cows (van Knegsel et al., 2007b). In line with this concept, Blum et al. (2000) observed that plasma BHBA concentrations were not correlated with plasma NEFA concentrations after feeding different fat sources over a 24 -h period in wk 9 and 19 of lactation in high-yielding dairy cows. On the one hand, plasma BHBA could come from the partial $\beta$-oxidation of NEFA in liver or from conversion of butyrate in rumen (Bergman, 1990). On the other 
hand, plasma BHBA could be used for synthesis of milk fat in the mammary gland (Bauman and Griinari, 2003) or as an alternative energy source for glucose in brain and muscles (Veech, 2004). In the current study, plasma BHBA concentrations was relatively low for all dry period lengths: on average lower than $1.2 \mathrm{mmol} / \mathrm{L}$, the threshold above which subclinical ketosis is indicated (Duffield et al., 1998).

In the current experiment, dry period length did not affect plasma BHBA concentrations, whereas dry period length had an effect on the energy balance in early lactation (van Knegsel et al., 2014). On the contrary, diet in early lactation did affect plasma BHBA concentrations. Cows fed lipogenic diet had greater plasma BHBA concentrations, compared with cows fed glucogenic diet, which is in line with our earlier study (van Knegsel et al., 2007b). This indicates that plasma BHBA concentration is more affected by diet composition than dry period length in early lactation. In addition, dry period length did affect plasma BHBA concentrations precalving. Cows with a 0-d dry period had greater plasma BHBA concentrations, compared with cows with a 30- or 60-d dry period, which is in line with earlier work (Andersen et al., 2005). The greater BHBA concentrations precalving could be related to greater DMI for cows with a 0-d dry period (van Knegsel et al., 2014) or the difference in diet composition, because these cows were fed a lactation diet during the precalving period.

The lack of effect of dry period length on plasma BHBA might suggest a similar rate of $\beta$-oxidation for the different dry period lengths in this study. Carnitine palmitoyltransferase $1 \mathrm{~A}$ and carnitine palmitoyltransferase 2 are enzymes that transport fatty acids into the mitochondria and are converted to ketone bodies through $\beta$-oxidation (McGarry and Brown, 1997). In early lactation, the lack of differences in CPT1A expression and the expression of genes related to ketogenesis (BDH2 and HMGCS2) may confirm that the similar rate of $\beta$-oxidation in the liver among all dry period lengths. In contrast, Wiedemann et al. (2013) observed a greater CPT1A mRNA expression in early lactation of continuously milked cows compared with cows with a conventional dry period. These differences between studies could be explained by the relatively low concentrations of NEFA for all dry period lengths in the current study, which may not be in the range of upregulating the CPT1A mRNA expression (van Dorland et al., 2009). Additional research is required to confirm this hypothesis. In addition, for all dry period lengths, the mRNA expression of CPT2 increased after calving. Graber et al. (2010) also reported increased mRNA expression of CPT2 in wk 4 postcalving com- pared with wk 3 precalving. van Dorland et al. (2012) observed that mRNA expression of CPT2 was greater for cows with greater plasma NEFA concentrations $(>500 \mu \mathrm{mol} / \mathrm{L})$ than for cows with lower NEFA concentrations $(<140 \mu \mathrm{mol} / \mathrm{L})$ at d 1 after calving, suggesting that expression of CPT2 in liver of dairy cows might be related to the NEFA concentration in plasma.

In nonruminants, ACLY is believed to be the key enzyme involved in cleavage of cytosolic citrate to generate acetyl-CoA from glucose (Hatzivassiliou et al., 2005). Then acetyl-CoA can be converted to malonyl-CoA, a pivotal precursor for the synthesis of fatty acids, by the ACC enzyme (Abu-Elheiga et al., 2001). In ruminants, Ballard et al. (1972) observed increased ACLY enzyme activity in response to a high-carbohydrate diet in the liver. In the current study, however, no effects of dry period length and diet were observed on mRNA expression of $A C L Y$ and $A C C$ in the liver. Khan et al. (2014) suggested that liver is not a lipogenic tissue in ruminants.

In the current study, expression of mRNA encoding SAA and Hp proteins increased from late pregnancy to early lactation independent of dry period length. The increased gene expression of acute phase proteins after calving has been suggested to be the result of a combination of bacterial contamination and involution of the uterus (Sheldon et al., 2001). Previous studies reported that serum concentrations of SAA and $\mathrm{Hp}$ peaked in the first week rather than the second week after calving (Nyman et al., 2008; Chan et al., 2010), which could partially explain the absence of the effects of dry period lengths on mRNA expression of $S A A$ and $H p$. Furthermore, elevated mRNA expression of $H p$ in wk 4 did not correspond to the findings of Chan et al. (2010), who observed that serum concentrations of $\mathrm{Hp}$ and SAA decreased to baseline values in the third week and first week after calving, respectively. In the current study, the elevated mRNA expression of $S A A$ and $H p$ in wk 4 could be associated with inflammatory diseases such as metritis and mastitis or noninfectious stressors such as tissue injury or psychosocial stressors (Colditz, 2002).

In several studies, hepatic gene expression was investigated in wk 1 after calving, because most genes involved in main metabolic and inflammatory processes change greatly at the time of initiation of lactation (Greenfield et al., 2000; Nyman et al., 2008; Wiedemann et al., 2013). In the current study, we investigated gene expression in wk 2 after calving, which was based on a previous study in which the energy balance reached nadir around 2 wk after calving (Rastani et al., 2005). Also, the nadirs of energy balance (van Knegsel et al., 2014), plasma concentrations of glucose, IGF-I, and 
insulin occurred around wk 2 for cows in the current study, indicating that cows experienced great metabolic challenges during wk 2 in lactation.

Precalving, cows with a 0-d dry period had not only greater plasma BHBA but also lower NEFA concentrations compared with cows with a 60-d dry period, which is in line with a previous study (Andersen et al., 2005). The lower plasma NEFA and liver TAG concentrations may be related to ongoing lactation in late pregnancy in cows with a 0-d dry period, because plasma NEFA could be absorbed and esterified by the mammary gland (Glasser et al., 2007). The greater plasma BHBA and urea concentrations precalving may be caused by greater nutrient absorption from greater feed intake and higher $\mathrm{CP}$ content in the diet of cows with a $0-\mathrm{d}$ dry period (Andersen et al., 2005). Additionally, greater concentrate intake precalving could explain the greater plasma insulin concentrations in cows with a 0-d dry period in the current study (Grummer, 1995). Further, the elevation of plasma NEFA concentrations and the decline of plasma IGF-I concentrations in weeks before calving in our experiment are commonly observed (Fenwick et al., 2008; de Feu et al., 2009; Schlamberger et al., 2010) and can be explained by the decreased feed intake and increased energy requirements during late pregnancy (Ingvartsen and Andersen, 2000).

Contrary to our expectations, no diet effects on plasma metabolites, hormones, liver TAG, or hepatic gene expression were found except for plasma urea and BHBA concentrations. Greater plasma BHBA and urea concentrations for cows fed a lipogenic diet, compared with cows fed a glucogenic diet, are in line with our earlier study (van Knegsel et al., 2007b). In contrast to this earlier study, the glucogenic diet in the current study did not decrease the mobilization of body fat and was not related to greater plasma insulin concentrations and lower plasma NEFA concentrations. The differences between studies are probably the result of a lower proportion of experimental concentrates used (8.5 vs. $12 \mathrm{~kg} / \mathrm{d}$ ) and smaller dietary contrast (less starch in the glucogenic diet; less fiber and fat in the lipogenic diet) in the current study compared with the previous study. The greater plasma urea concentrations in cows fed a lipogenic diet, compared with cows fed a glucogenic diet, is consistent with our previous study (van Knegsel et al., 2007b). This could be related to the use of glucogenic amino acids for gluconeogenesis.

\section{CONCLUSIONS}

In the current study, omission of the dry period (0-d) but not shortening the dry period (30-d) resulted in an improved metabolic status of dairy cows in early lactation compared with a conventional dry period (60-d). This improvement was associated with less body fat mobilization because of reduced milk yield, as indicated by decreased plasma NEFA and liver TAG concentrations, and increased plasma insulin, glucose, and IGF-I concentrations. The improved metabolic status in cows with a 0-d dry period was confirmed by the lower mRNA expression of $P C$ in early lactation. Independent of dry period length, a glucogenic diet also improved the metabolic status, as indicated by lower plasma BHBA and urea concentrations, compared with a lipogenic diet.

\section{ACKNOWLEDGMENTS}

The authors thank the Dutch Dairy Board (PZ, the Netherlands), Product Board Animal Feed (PDV; the Netherlands), and CRV (the Netherlands) for financing the experiment. The first author thanks the Chinese Scholarship Council (CSC) for financial support. Additionally, the authors thank the staff of the Dairy Campus (Lelystad, the Netherlands) and Yolande Zbinden, Claudine Morel, and Olga Wellnitz from the Veterinary Physiology Group of the University of Bern for their technical support and laboratory analyses during the experiment.

\section{REFERENCES}

Abu-Elheiga, L., M. M. Matzuk, K. A. Abo-Hashema, and S. J. Wakil. 2001. Continuous fatty acid oxidation and reduced fat storage in mice lacking acetyl-CoA carboxylase 2. Science 291:2613-2616.

Andersen, J. B., T. Madsen, T. Larsen, K. L. Ingvartsen, and M. Nielsen. 2005. The effects of dry period versus continuous lactation on metabolic status and performance in periparturient cows. J. Dairy Sci. 88:3530-3541.

Aschenbach, J. R., N. B. Kristensen, S. S. Donkin, H. M. Hammon, and G. B. Penner. 2010. Gluconeogenesis in dairy cows: The secret of making sweet milk from sour dough. IUBMB Life 62:869-877.

Bachman, K. C., and M. L. Schairer. 2003. Invited review: Bovine studies on optimal lengths of dry periods. J. Dairy Sci. 86:30273037.

Ballard, F., O. Filsell, and I. Jarrett. 1972. Effects of carbohydrate availability on lipogenesis in sheep. Biochem. J. 126:193-200.

Bauman, D. E., and J. M. Griinari. 2003. Nutritional regulation of milk fat synthesis. Annu. Rev. Nutr. 23:203-227.

Bell, A. W. 1995. Regulation of organic nutrient metabolism during transition from late pregnancy to early lactation. J. Anim. Sci. $73: 2804-2819$.

Bergman, E. 1990. Energy contributions of volatile fatty acids from the gastrointestinal tract in various species. Physiol. Rev. 70:567-590.

Blum, J., R. Bruckmaier, P. Y. Vacher, and F. Jans. 2000. Twentyfour-hour patterns of hormones and metabolites in week 9 and 19 of lactation in high-yielding dairy cows fed triglycerides and free fatty acids. J. Vet. Med. A Physiol. Pathol. Clin. Med. 47:43-60.

Bobe, G., J. Young, and D. Beitz. 2004. Invited review: Pathology, etiology, prevention, and treatment of fatty liver in dairy cows. J. Dairy Sci. 87:3105-3124.

Butler, S. T., A. Marr, S. Pelton, R. Radcliff, M. C. Lucy, and W. Butler. 2003. Insulin restores GH responsiveness during lactation- 
induced negative energy balance in dairy cattle: Effects on expression of IGF-I and GH receptor 1A. J. Endocrinol. 176:205-217.

Butler, W. 2003. Energy balance relationships with follicular development, ovulation and fertility in postpartum dairy cows. Livest. Prod. Sci. 83:211-218

Chagas, L., J. Bass, D. Blache, C. Burke, J. Kay, D. Lindsay, M. Lucy, G. Martin, S. Meier, and F. Rhodes. 2007. Invited review: New perspectives on the roles of nutrition and metabolic priorities in the subfertility of high-producing dairy cows. J. Dairy Sci. 90:4022-4032.

Chan, J. P. W., C. C. Chang, W. L. Hsu, W. B. Liu, and T. H Chen. 2010. Association of increased serum acute-phase protein concentrations with reproductive performance in dairy cows with postpartum metritis. Vet. Clin. Pathol. 39:72-78.

Colditz, I. 2002. Effects of the immune system on metabolism: Implications for production and disease resistance in livestock. Livest. Prod. Sci. 75:257-268.

de Feu, M., A. Evans, P. Lonergan, and S. T. Butler. 2009. The effect of dry period duration and dietary energy density on milk production, bioenergetic status, and postpartum ovarian function in Holstein-Friesian dairy cows. J. Dairy Sci. 92:6011-6022.

Drackley, J. K., T. R. Overton, and G. N. Douglas. 2001. Adaptations of glucose and long-chain fatty acid metabolism in liver of dairy cows during the periparturient period. J. Dairy Sci. 84:E100E112.

Duffield, T., D. Sandals, K. Leslie, K. Lissemore, B. McBride, J. Lumsden, P. Dick, and R. Bagg. 1998. Efficacy of monensin for the prevention of subclinical ketosis in lactating dairy cows. J. Dairy Sci. 81:2866-2873.

Fenwick, M. A., R. Fitzpatrick, D. A. Kenny, M. G. Diskin, J. Patton, J. J. Murphy, and D. C. Wathes. 2008. Interrelationships between negative energy balance (NEB) and IGF regulation in liver of lactating dairy cows. Domest. Anim. Endocrinol. 34:31-44.

Gessner, D., G. Schlegel, J. Keller, F. Schwarz, R. Ringseis, and K. Eder. 2013. Expression of target genes of nuclear factor E2-related factor 2 in the liver of dairy cows in the transition period and at different stages of lactation. J. Dairy Sci. 96:1038-1043.

Glasser, F., M. Doreau, A. Ferlay, and Y. Chilliard. 2007. Technical note: Estimation of milk fatty acid yield from milk fat data. J Dairy Sci. 90:2302-2304.

Graber, M., S. Kohler, T. Kaufmann, M. G. Doherr, R. M. Bruckmaier, and H. A. van Dorland. 2010. A field study on characteristics and diversity of gene expression in the liver of dairy cows during the transition period. J. Dairy Sci. 93:5200-5215.

Graber, M., S. Kohler, A. Muller, K. Burgermeister, T. Kaufmann, R. M. Bruckmaier, and H. A. van Dorland. 2012. Identification of plasma and hepatic parameters related to metabolic robustness in dairy cows. J. Anim. Physiol. Anim. Nutr. (Berl.) 96:75-84.

Grala, T., M. Lucy, C. Phyn, A. Sheahan, J. Lee, and J. Roche. 2011 Somatotropic axis and concentrate supplementation in grazing dairy cows of genetically diverse origin. J. Dairy Sci. 94:303-315.

Greenfield, R., M. Cecava, and S. Donkin. 2000. Changes in mRNA expression for gluconeogenic enzymes in liver of dairy cattle during the transition to lactation. J. Dairy Sci. 83:1228-1236.

Gross, J., H. van Dorland, F. Schwarz, and R. Bruckmaier. 2011. Endocrine changes and liver mRNA abundance of somatotropic axis and insulin system constituents during negative energy balance at different stages of lactation in dairy cows. J. Dairy Sci. 94:3484-3494.

Grummer, R., and R. Rastani. 2004. Why reevaluate dry period length? J. Dairy Sci. 87:E77-E85.

Grummer, R. R. 1995. Impact of changes in organic nutrient metabolism on feeding the transition dairy cow. J. Anim. Sci. 73:28202833.

Gümen, A., R. Rastani, R. Grummer, and M. Wiltbank. 2005. Reduced dry periods and varying prepartum diets alter postpartum ovulation and reproductive measures. J. Dairy Sci. 88:2401-2411.

Hatzivassiliou, G., F. Zhao, D. E. Bauer, C. Andreadis, A. N. Shaw, D. Dhanak, S. R. Hingorani, D. A. Tuveson, and C. B. Thompson. 2005. ATP citrate lyase inhibition can suppress tumor cell growth. Cancer Cell 8:311-321.
Ingvartsen, K. L., and J. B. Andersen. 2000. Integration of metabolism and intake regulation: A review focusing on periparturient animals. J. Dairy Sci. 83:1573-1597.

Khan, M. J., C. B. Jacometo, D. E. Graugnard, M. N. Corrêa, E. Schmitt, F. Cardoso, and J. J. Loor. 2014. Overfeeding dairy cattle during late-pregnancy alters hepatic PPAR $\alpha$-regulated pathways including hepatokines: Impact on metabolism and peripheral insulin sensitivity. Gene Regul. Syst. Bio. 8:97.

Klusmeyer, T. H., A. C. Fitzgerald, A. C. Fabellar, J. M. Ballam, R A. Cady, and J. L. Vicini. 2009. Effect of recombinant bovine somatotropin and a shortened or no dry period on the performance of lactating dairy cows. J. Dairy Sci. 92:5503-5511.

Lemosquet, S., G. Raggio, G. Lobley, H. Rulquin, J. Guinard-Flament, and H. Lapierre. 2009. Whole-body glucose metabolism and mammary energetic nutrient metabolism in lactating dairy cows receiving digestive infusions of casein and propionic acid. J. Dairy Sci. 92:6068-6082.

Locher, L., N. Meyer, E.-M. Weber, J. Rehage, U. Meyer, S. Dänicke, and K. Huber. 2011. Hormone-sensitive lipase protein expression and extent of phosphorylation in subcutaneous and retroperitoneal adipose tissues in the periparturient dairy cow. J. Dairy Sci 94:4514-4523.

Loor, J. J., H. M. Dann, R. E. Everts, R. Oliveira, C. A. Green, N. Guretzky, S. L. Rodriguez-Zas, H. A. Lewin, and J. K. Drackley. 2005. Temporal gene expression profiling of liver from periparturient dairy cows reveals complex adaptive mechanisms in hepatic function. Physiol. Genomics 23:217-226.

Loor, J. J., H. M. Dann, N. A. J. Guretzky, R. E. Everts, R. Oliveira, C. A. Green, N. B. Litherland, S. L. Rodriguez-Zas, H. A. Lewin, and J. K. Drackley. 2006. Plane of nutrition prepartum alters hepatic gene expression and function in dairy cows as assessed by longitudinal transcript and metabolic profiling. Physiol. Genomics 27:29-41.

Lucy, M., H. Jiang, and Y. Kobayashi. 2001. Changes in the somatotrophic axis associated with the initiation of lactation. J. Dairy Sci. 84:E113-E119.

McGarry, J. D., and N. F. Brown. 1997. The mitochondrial carnitine palmitoyltransferase system-From concept to molecular analysis. Eur. J. Biochem. 244:1-14.

Nyman, A.-K., U. Emanuelson, K. Holtenius, K. L. Ingvartsen, T Larsen, and K. Persson Waller. 2008. Metabolites and immune variables associated with somatic cell counts of primiparous dairy cows. J. Dairy Sci. 91:2996-3009.

Radcliff, R., B. McCormack, B. Crooker, and M. Lucy. 2003. Plasma hormones and expression of growth hormone receptor and insulinlike growth factor-I mRNA in hepatic tissue of periparturient dairy cows. J. Dairy Sci. 86:3920-3926.

Rastani, R., R. Grummer, S. Bertics, A. Gümen, M. Wiltbank, D. Mashek, and M. Schwab. 2005. Reducing dry period length to simplify feeding transition cows: Milk production, energy balance, and metabolic profiles. J. Dairy Sci. 88:1004-1014.

Schlamberger, G., S. Wiedemann, E. Viturro, H. Meyer, and M. Kaske. 2010. Effects of continuous milking during the dry period or once daily milking in the first 4 weeks of lactation on metabolism and productivity of dairy cows. J. Dairy Sci. 93:2471-2485.

Sheldon, I., D. Noakes, A. Rycroft, and H. Dobson. 2001. Acute phase protein responses to uterine bacterial contamination in cattle after calving. Vet. Rec. 148:172-175.

Takeuchi, K., and K. Reue. 2009. Biochemistry, physiology, and genetics of GPAT, AGPAT, and lipin enzymes in triglyceride synthesis. Am. J. Physiol. Endocrinol. Metab. 296:E1195-E1209.

Tamminga, S., W. Van Straalen, A. Subnel, R. Meijer, A. Steg, C. Wever, and M. Blok. 1994. The Dutch protein evaluation system: The DVE/OEB-system. Livest. Prod. Sci. 40:139-155.

van Dorland, H. A., S. Richter, I. Morel, M. G. Doherr, N. Castro, and R. M. Bruckmaier. 2009. Variation in hepatic regulation of metabolism during the dry period and in early lactation in dairy cows. J. Dairy Sci. 92:1924-1940.

van Dorland, H. A, H. Sadri, I. Morel, and R. Bruckmaier. 2012. Coordinated gene expression in adipose tissue and liver differs between 
cows with high or low NEFA concentrations in early lactation. J. Anim. Physiol. Anim. Nutr. (Berl.) 96:137-147.

Van Es, A. 1975. Feed evaluation for dairy cows. Livest. Prod. Sci. 2:95-107.

van Knegsel, A., G. Remmelink, S. Jorjong, V. Fievez, and B. Kemp. 2014. Effect of dry period length and dietary energy source on energy balance, milk yield, and milk composition of dairy cows. J. Dairy Sci. 97:1499-1512.

van Knegsel, A., H. Van den Brand, J. Dijkstra, W. Van Straalen, R. Jorritsma, S. Tamminga, and B. Kemp. 2007a. Effect of glucogenic vs. lipogenic diets on energy balance, blood metabolites, and reproduction in primiparous and multiparous dairy cows in early lactation. J. Dairy Sci. 90:3397-3409.

van Knegsel, A., H. Van den Brand, E. Graat, J. Dijkstra, R. Jorritsma, E. Decuypere, S. Tamminga, and B. Kemp. 2007b. Dietary energy source in dairy cows in early lactation: Metabolites and metabolic hormones. J. Dairy Sci. 90:1477-1485.

van Knegsel, A., S. G. van der Drift, J. Čermáková, and B. Kemp. 2013. Effects of shortening the dry period of dairy cows on milk production, energy balance, health, and fertility: A systematic review. Vet. J. 198:707-713.
Vandesompele, J., K. De Preter, F. Pattyn, B. Poppe, N. Van Roy, A. De Paepe, and F. Speleman. 2002. Accurate normalization of real-time quantitative RT-PCR data by geometric averaging of multiple internal control genes. Genome Biol. 3:research0034.0031-0034.0011.

Veech, R. L. 2004. The therapeutic implications of ketone bodies: The effects of ketone bodies in pathological conditions: Ketosis, ketogenic diet, redox states, insulin resistance, and mitochondrial metabolism. Prostaglandins Leukot. Essent. Fatty Acids 70:309-319.

Vicari, T., J. Van den Borne, W. Gerrits, Y. Zbinden, and J. Blum. 2008. Postprandial blood hormone and metabolite concentrations influenced by feeding frequency and feeding level in veal calves. Domest. Anim. Endocrinol. 34:74-88.

Wiedemann, S., G. Sigl, C. Schmautz, M. Kaske, E. Viturro, and H. H. Meyer. 2013. Omission of dry period or milking once daily affects metabolic status and is reflected by mRNA levels of enzymes in liver and muscle of dairy cows. Livest. Sci. 154:193-203.

Zarrin, M., O. Wellnitz, H. van Dorland, and R. Bruckmaier. 2014 Induced hyperketonemia affects the mammary immune response during lipopolysaccharide challenge in dairy cows. J. Dairy Sci. 97:330-339. 